\title{
The legacy of Big South Cape: rat irruption to rat eradication
}

\author{
Elizabeth A. Bel1 ${ }^{1, *}$, Brian D. Bell ${ }^{2}$, Don V. Merton ${ }^{3}$ \\ ${ }^{1}$ Corresponding author: Wildlife Management International Ltd., PO Box 607, Blenheim 7240, New Zealand \\ 235 Selmes Road, Rapaura, RD3, Blenheim 7273 \\ ${ }^{3}$ Deceased \\ * Author for correspondence (Email: biz@wmil.co.nz)
}

Published online: 12 January 2016

\begin{abstract}
Big South Cape Island (Taukihepa) is a 1040 ha island, $1.5 \mathrm{~km}$ from the southwest coast of Stewart Island/Rakiura, New Zealand. This island was rat-free until the incursion of ship rats (Rattus rattus) in, or shortly before, 1963, suspected to have been accidentally introduced via local fishing boats that moored at the island with ropes to the shore, and were used to transport the mutton birders to the island. This incursion was reported by the muttonbirders - local Iwi who harvest the young of titi (sooty shearwater, Puffinus griseus) - to the then New Zealand Wildlife Service (via the New Zealand Department of Lands and Survey). Investigation into the reports found ship rats had reached the island and had decimated the local land bird populations. Brian Bell and Don Merton attempted some of the first translocations of South Island saddleback (Philesturnus c. carunculatus), Stewart Island snipe (Coenocorypha aucklandica iredalei) and Stead's bush wren (Xenicus longipes variabilis) with only the saddleback being successful. Extinctions of the snipe, wren and greater short-tailed bat (Mystacina robusta) were recorded. This was the first time rats were definitively recognised as the cause of extinction of native land birds and directed further debate into the impacts of rats and how to deal with them.
\end{abstract}

Keywords: Big South Cape, saddleback, wren, snipe, rat, Rattus rattus, short-tailed bat, titi/sooty shearwater, eradication, irruption

\section{Introduction}

Since the introduction of rats (ship rat Rattus rattus, Norway rat $R$. norvegicus and Pacific rat or kiore $R$. exulans), New Zealand's offshore islands have been the focus of conservation management as last refuges for many endemic species. The rat-free status of islands has not always been maintained, with rats reaching the shores by accident (via boat transportation) or by swimming between islands, or between islands and the mainland. These invasions have caused local and global extinctions and in response, New Zealand has led international efforts in island restoration by developing techniques to translocate endangered birds to rat-free islands and to eradicate rats from islands (Clout \& Russell 2006; Bellingham et al. 2010). Rat eradication technology has moved from eradications on small islands during control programmes in the 1970 s to the complex operations on large islands currently being completed. This paper reports on the rat incursion, subsequent irruption and impacts on endemic species on Big South Cape Island/ Taukihepa in the early 1960s and how this event influenced endangered species management, rat eradication technology and island restoration practices.

\section{Big South Cape Island/Taukihepa}

Big South Cape Island/Taukihepa (BSC) is the largest island (1040 ha) in the Big South Cape group (BSC, Poutama, Putauhina, Pohowaitai and Solomon Islands) (Figure 1). BSC is $1.5 \mathrm{~km}$ offshore from the south-western coast of Stewart Island/Rakiura. Rising to $235 \mathrm{~m}$, BSC has habitats ranging from coastal Olearia scrub and punui (Stilbocarpa lyallii) to rata (Metrosideros umbellata) and podocarp forest and pakihi heathland at the top of the island (Bell 1978). A number of unique species have been recorded on BSC including South Island saddleback (Philesturnus carunculatus carunculatus),
Stead's bush wren (Xenicus longipes variabilis) and Stewart Island snipe (Coenocorypha aucklandica iredalei) (Miskelly $\&$ de Lange 2006; Gill et al. 2010). The island was visited by naturalists (including Herbert Guthrie-Smith, Edgar Stead, Major Robert Wilson and Sir Robert Falla) who made numerous notes and completed studies on the birdlife (Guthrie-Smith 1925; Guthrie-Smith 1936; Stead 1936; Wilson 1959). These naturalists recognised the importance of $\mathrm{BSC}$ as a rat-free refuge, with Guthrie-Smith stating that it "was an ark for native bird species" and stressing how different it was from islands that had rats present, and Stead and Wilson recommending that $\mathrm{BSC}$ be protected due to its value to conservation. Authors (BDB and DVM) visited BSC in April 1961 to survey the island, assess the level of harvest by the muttonbirding families - local Iwi who harvest the young of titi (sooty shearwater, Puffinus griseus) - and discuss the protection of the island and species that live there. Traditional muttonbirding has been ongoing on BSC for several hundred years with annual visits occurring for six to eight weeks between April and May. At the time of the 1961 survey, the Department of Lands and Survey supervised the muttonbird season in conjunction with the Iwi Muttonbird Committee.

\section{Rat irruption}

A single rat (Rattus rattus) was trapped at Murderer's Cove on BSC in January 1955 by Thane Riney during a National Museum expedition, but subsequent visits by New Zealand Wildlife Service (NZWS) personnel in 1956 (Logan Bell) and 1961 (BDB and DVM) did not detect any rats (Riney 1955; Bell 1978). Given Logan Bell trapped kiore on nearby Putauhina Island during his 1956 visit to the area (Watson 1956), it can be expected that he would have reported any rats that he saw or had trapped on BSC at the same time. Concern about the number of rats seen on-board fishing boats used by 


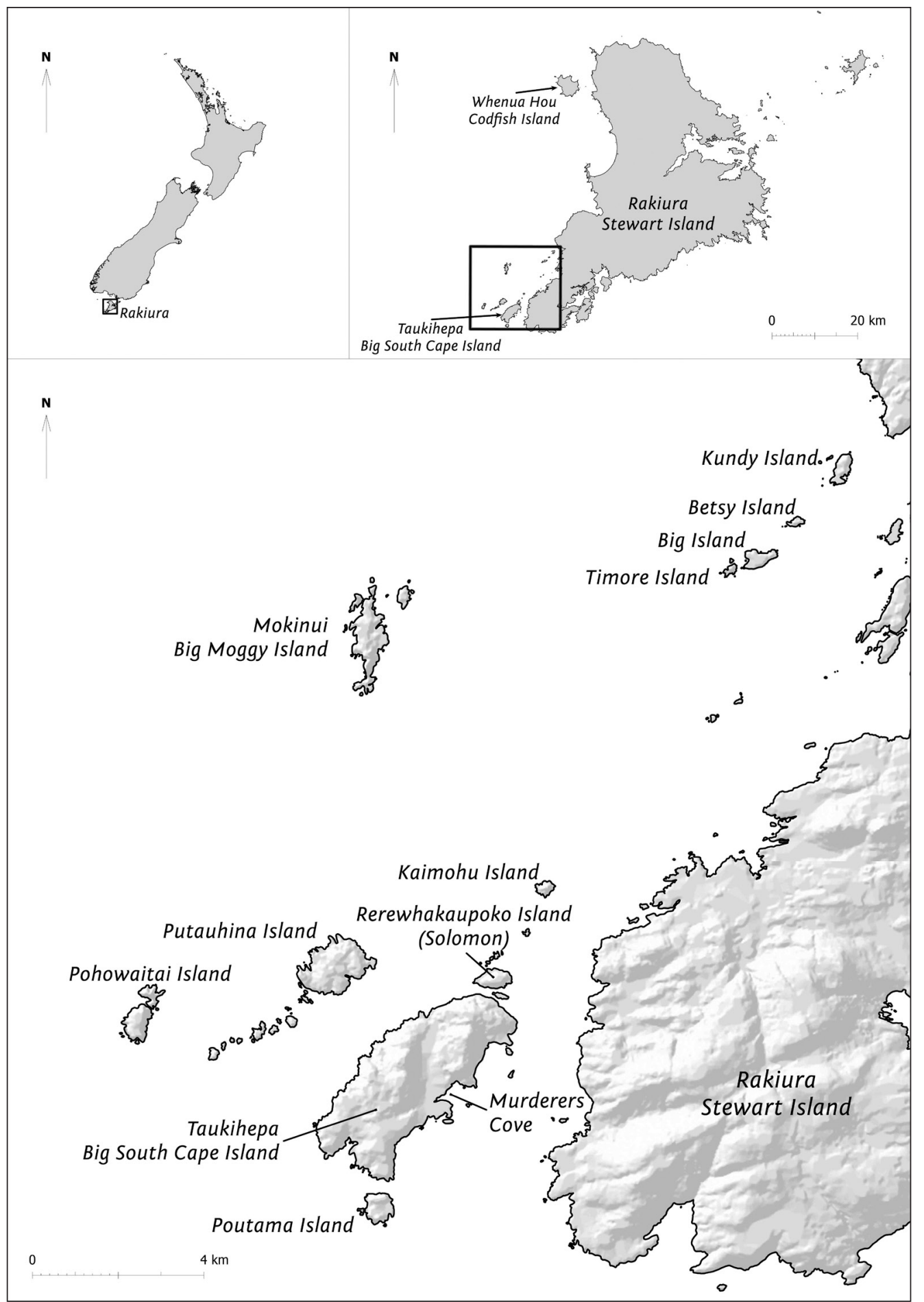

Figure 1. Location of Big South Cape Island/Taukihepa. Map data sourced from the LINZ Data Service and licensed by LINZ for re-use under the Creative Commons Attribution 3.0 New Zealand licence.

the muttonbird families when visiting the island and moored with ropes onto the shore had raised the question of biosecurity options. BDB discussed these concerns and outlined basic biosecurity techniques with the families on BSC in 1961.

The muttonbirding families reported the presence of rats at Murderer's Cove on BSC to the Department of Lands and Survey in February 1964 whom immediately passed this information onto the NZWS in March 1964. The muttonbirders had arrived to find their huts on the island had been significantly damaged by rats with wallpaper stripped to the level that rats could reach when eating the wallpaper paste (Figure 2). All food and other supplies stored on the island had been eaten or damaged and rat droppings and urine covered the beds and floors (Figure 2). The families were concerned that the presence of rats would impact on the number of muttonbirds available during the harvest. The rats are believed to have reached BSC via a fishing boat from a southern New Zealand port such as the crayfish fishers from Fiordland or Port Chalmers in, or before 1963, as Boy Hanning mentioned to BDB later that he had seen rat damage on potatoes in his hut at the northern end of Murderer's Cove the previous season (May 1963). Recent analysis using DNA from rats collected off BSC at the time of the irruption suggests that these rats came from areas away from Stewart Island or the South Island south coast (Robins 


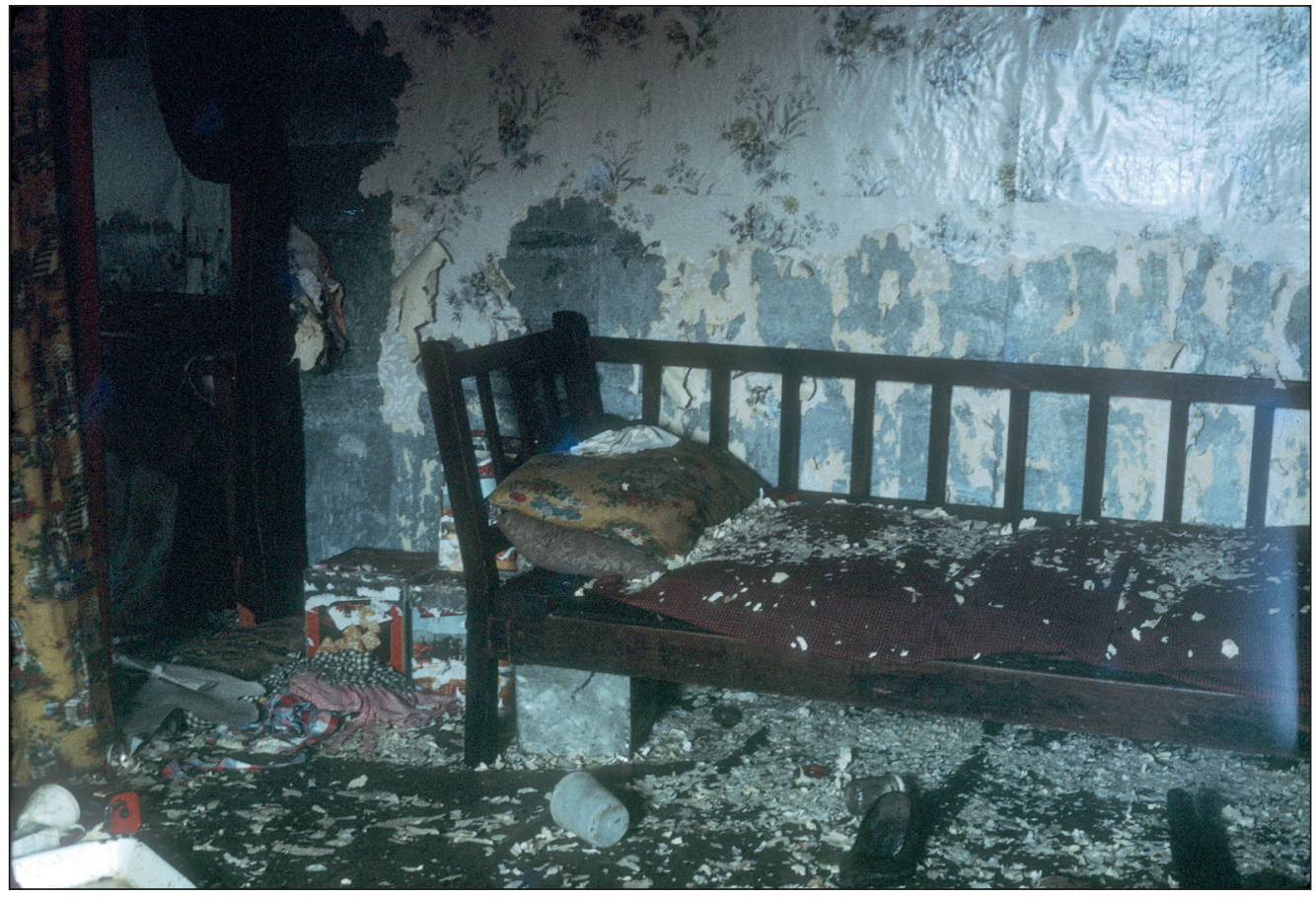

Figure 2. Damage by ship rats (Rattus rattus) to the Waitiri family muttonbird hut on Big South Cape Island/Taukihepa, April 1964. Photo by Brian Bell.

et al. 2016), supporting this origin hypothesis.

The Southland Acclimatisation Society (Jim Macintosh and Lionel Lobb) and the Forest \& Bird Society (Les Henderson) provided funding to purchase rodenticide (warfarin) that was placed out immediately around the huts and on neighbouring Solomon Island during March 1964. This baiting continued through to the end of 1965 (Blackburn 1965). These agencies felt it was important to implement management actions to deal with the rats on the island to protect the birds, plants and invertebrates. This position was opposed by a number of people including Sir Robert Falla (Chairman of the Nature Conservation Council) who thought it was more important to monitor the situation as they felt the birds and rats would eventually reach a balance (Bell 1978; Galbreath 1993). Due to concern for the native species on BSC, and local pressure from Iwi, the Forest \& Bird Protection Society and Southland Acclimatisation Society pushed the Government agencies to act.

The Department of Internal Affairs (Jack Meech) and NZWS (particularly Frank Newcombe and Henry Kelly) called for an urgent assessment of the situation and to study the rat irruption on BSC, and tried to obtain support and assistance from DSIR, the National Museum and universities without success. With the support of, and funding from, the Department of Lands and Survey, BDB and Jim O'Brien (NZWS) visited BSC in April 1964. They recognised that there was already a dire situation for the birds on the island with numbers seriously depleted and most of them gone from the northern half of the island. Following this assessment, NZWS determined that as many species as possible needed to be saved and approvals were urgently obtained to undertake a salvage operation. BDB confirmed the rat species on the island was Rattus rattus.

Supported by the New Zealand Navy Fisheries Protection Squad, BDB, DVM, Jim O'Brien, John Gibbs, Dick Veitch and Peter Johns visited BSC in August-September 1964 to salvage the situation. The impacts of rats on the ecology of the island were already immense; there was absolute silence over most of the island, with robin (Petroica australis australis) and fernbirds (Bowdleria punctata) already extirpated and saddleback and bellbirds (Anthornis melanura) restricted to the southern end. Much of the vegetation, in particular punui and five-finger (Pseudopanax spp.) had been denuded or eaten to the bases, and no seeds or seedlings could be seen throughout the forest.

BDB recognised the need for the immediate capture and translocation of birds to neighbouring rat-free islands. Several of the close islands were assessed by BDB and Dick Veitch for suitability for transfer, while DVM and the remaining team members constructed temporary aviaries and began to catch saddleback, wrens and snipe. The weather during this winter period was foul with gale force winds, hail storms and rough seas which delayed the team reaching the island by two weeks and made all survey and bird capture work difficult. BDB identified that larger rat-free islands were needed as the translocation sites; Codfish Island was assessed while the Navy vessel was sheltering from the storm, but it was deemed unsuitable due to the presence of kiore. Big and Kaimohu Islands were assessed next, followed by Kundy and Betsy Islands; Big and Kaimohu were chosen as they were rat-free and were the largest islands available with suitable habitat for each of the species to be transferred in close proximity to BSC.

The Natural History Unit(Television New Zealand) visited the islands in the early 1980s to document the incursion, the impacts of rats and the action taken following this event (Island eaten by rats: Wild South Volume 2: 1984).

\section{South Island Saddleback}

Building on earlier work on the North Island saddleback ( $P$. c. rufusater) (Merton 1965), 36 saddleback were caught in the forest using mist nets, and by hand nets when the birds were roosting at night in the huts. These birds were kept in an aviary and fed. They were transferred to Kaimohu Island $(n=15)$ and Big Island $(n=21)$. A second capture session occurred in June 1965 with 30 birds being caught. These 
were transferred to Nukuwaiata Island (Chetwode Group, Marlborough). This second translocation was a failure due to the presence of kiore and weka (Gallirallus australis) (Merton 1975; Lovegrove 1996).

\section{Stewart Island snipe}

Snipe were restricted to the top of the island following the introduction of weka to BSC in the 1920s and were already in very low numbers. They were difficult to catch; having to be flushed, followed, flushed again and caught with hand nets. Three birds were caught. One escaped and two male birds were placed in an aviary. They proved difficult to care for in captivity, requiring a continuous supply of food, and both died prior to transfer.

\section{Stead's bush wren}

The bush wren were difficult to capture. They were very secretive and due to their size and behaviour did not fly with enough speed or force to drop into the pockets of the mist net. The wrens could also fit through the mist net (mist nets were only available in one size, $37 \mathrm{~mm}$ mesh, at this time). Capturing birds required the team to drop the net each time a bird was seen to hopefully entangle the bird in the whole net. Nine birds were captured and kept in an aviary. They needed large amounts of live food that was difficult to obtain on the island as the invertebrate fauna had also been depleted by the rats. Three birds died in captivity and the remaining six were transferred to Kaimohu Island. They did not survive, with the last individual being seen in 1972 by Daryl Munro when he visited the island with NZWS Officer Ron Nilsson (Ballance 2007).

\section{Greater short-tailed bat}

BDB and DVM reported that the greater short-tailed bat (Mystacina robusta) was abundant in the "bat cave" (Figure 3 ) and they even mist-netted two individuals on BSC in 1961. The bat was not recognised as a separate species at the time of the irruption (and was considered to be the lesser short-tailed bat $M$. t. tuberculata; Daniel 1990) and as a result there was no attempt to transfer them. Rats preyed on the bats and this species disappeared. The last official sighting was reported in 1965 (Blackburn 1965). O'Donnell (1999) reported that unusual echolocation calls were recorded by bat detectors on Putauhina Island in 1999 and speculated that great short-tailed bats may still be extant. However recent surveys have not detected any individuals (O’Donnell et al. 2010).

\section{Titi/sooty shearwater}

Although there was little immediate evidence that the rat irruption was affecting the number of titi on BSC, Rattus rattus had been shown to be a significant predator of burrowing seabirds (Atkinson 1985). Research from the Titi Islands around Stewart Island, beach patrol records, harvest rates, and at-sea counts have suggested that there has since been an overall decline in titi numbers and reduced productivity between 1961 and 2006 (Lyver 1999; Lyvver et al. 1999; Scofield \& Christie 2002; Moller et al. 2009; Clucas 2011; Clucas et al. 2012).

\section{Eradication and restoration}

In 1998, an oil spill from the tanker Command occurred on the Californian coast and killed thousands of seabirds including an estimated 32,000 titi (Moller et al. 2003; Bellingham et al. 2010; McClelland et al. 2011). Eleven titi were recovered on beaches including one banded on Whenau Hou (Codfish Island). The discovery of this bird allowed Rakiura Māori and Otago University to apply for mitigation funding through the Command Oil Spill Trustee Council. With the assistance of Oikonos Ecosystem Knowledge, funding was received to study the productivity of titi and sustainability of muttonbird harvesting (under the Kia Mau Te Tìtì Mo Ake Tōnu Atu project) and to restore privately owned islands through the eradication of rats, which was overseen by the non-profit group, Ka Mate Nga Kiore (Moller et al. 2003; Moller et al. 2009; Bellingham et al. 2010; McClelland et al. 2011). The

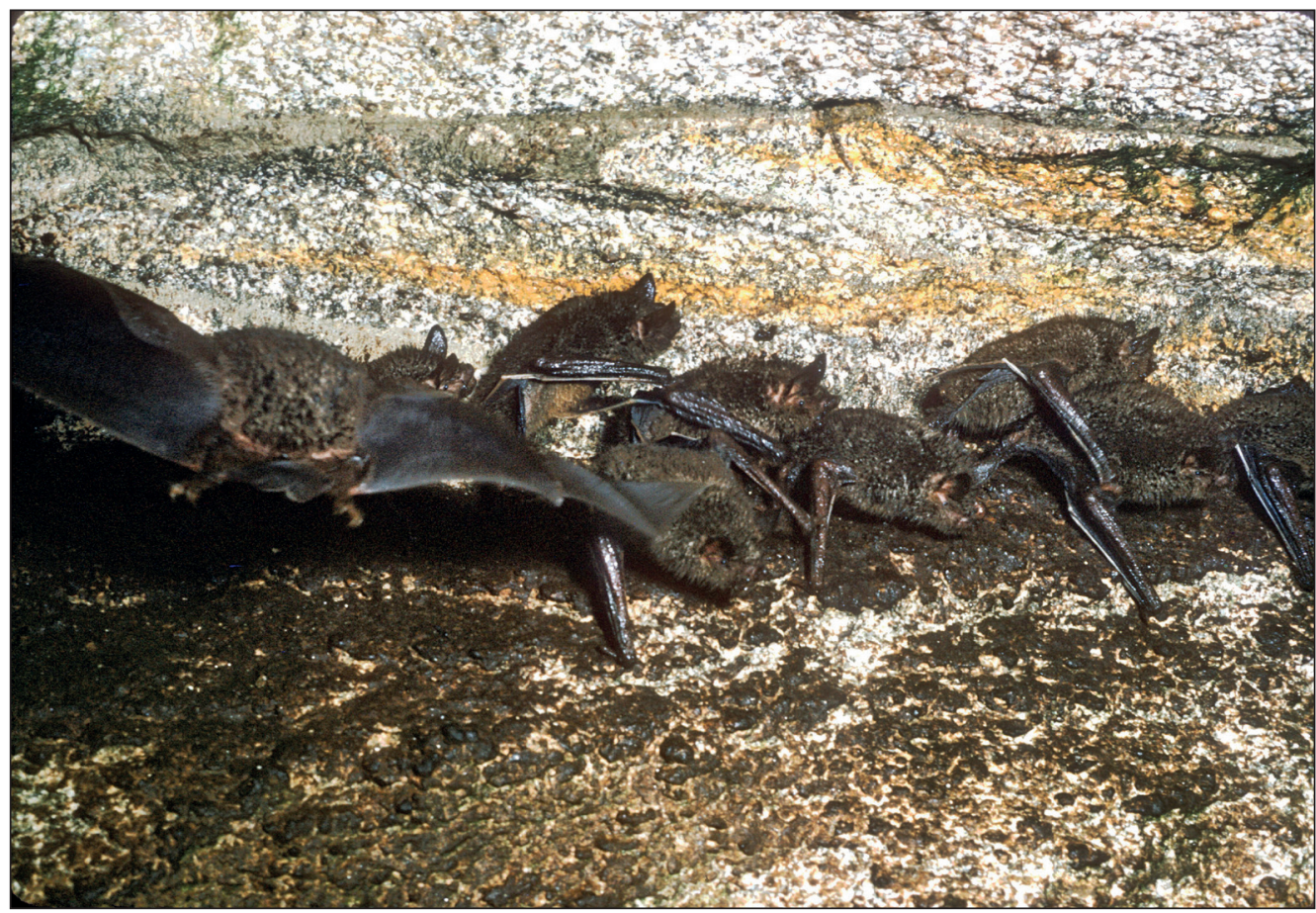

Figure 3. Greater short-tailed bats (Mystacina robusta) in the "bat cave", Big South Cape Island/Taukihepa, April 1961. Photo by Brian Bell. 
rats on BSC were eradicated in 2006 in an aerial operation using Pestoff 20R pellets containing $20 \mathrm{ppm}$ brodifacoum (McClelland et al. 2011). Following the eradication, Ka Mate Nga Kiore has provided support for improved biosecurity to the islands including an on-going education programme involving information signage at departure points, public displays, brochures and short films and practical advice (P. McClelland pers. comm.; McClelland et al. 2011). Following the eradication and declaration of rat-free status in 2009 , saddleback were returned to BSC in 2011 (38 birds) and in 2012 (42 birds) (P. McClelland pers. comm.; Miskelly \& Powlesland 2013). Land-bird, invertebrate, reptile numbers and vegetation cover have also increased since the eradication (Nevins \& Hester 2013).

\section{Discussion}

Big South Cape was one of the first multi-agency conservation management projects in New Zealand. Iwi, Government departments, conservation groups and local businesses all worked together to identify, assess and implement management actions to rescue endangered species from the impacts of rats. Once rats were reported on BSC, the transfer of saddleback and wren to Kaimohu and Big Islands was undertaken within five months; a relatively short time given the time needed to obtain approvals, assemble staff, arrange transport, survey the nearby islands for suitable rat-free sites, capture the birds and complete the transfers.

In retrospect, the capture of the single rat in 1955 is believed to be an independent incursion that did not result in establishment; it was certainly not the 'lag' period that was proposed by Falla in the 1976 symposium on the ecology and control of rats (Bell 1978). This theory is further supported by the fact that the later surveys in 1956 and 1961 did not detect rats on BSC while kiore were reported from nearby Putauhina Island in 1956 (Watson 1956; Bell 1978).

Recognised as one of the worst ecological disasters in New Zealand history, we consider that the BSC rat irruption changed the way many people thought about rats and their impacts on native species. Atkinson (1973) reported that the spread of ship rats across New Zealand coincided with the decline and extinction of a number of native birds. Despite the BSC event and growing evidence that rats were having an effect on New Zealand wildlife, at the symposium on the ecology and control of rodents in 1976, many eminent ecologists simply did not believe that rats caused the extinction of the native bird species on BSC (Bell 1978; Dingwall et al. 1978).

Despite the large areas of native habitat still present on the New Zealand mainland, endemic species were either no longer present or only in very low numbers on the mainland. Following the BSC rat irruption, it was finally understood by some people that New Zealand native species had established in the absence of mammals and as such, could not survive on the mainland in the presence of introduced mammals. Many leading scientists of the day were adamant that the restricted range of native species was not due to introduced mammals, which were then considered as part of the natural ecological system, but was instead primarily due to habitat destruction and fragmentation (Bell 1978).

They also did not believe that rats could be completely exterminated from islands (Bell 1978). However the eradication of rats from islands had already occurred on Maria Island and the David Rocks in the Noises Group, and Titi Island in
Marlborough following bait being laid to control rats on these islands (Bell 1969; Moors 1985; Thomas \& Taylor 2002). A result of these eradications was that ecologists and researchers worked towards developing better eradication techniques starting with ground-based bait station operations (Crawley 1983; Veitch \& Bell 1990; Thomas \& Taylor 2002; Towns \& Broome 2003). As these techniques proved successful, the attitude towards targeting rats on islands changed. A wider range of effective methods and tools were developed including aerial application of bait and different rodenticides. These advancements have meant larger islands and more complex operations could be completed (Veitch \& Bell 1990; Thomas \& Taylor 2002; Towns \& Broome 2003; Clout \& Russell 2006; Russell \& Broome 2016).

The rat irruption and subsequent loss of four species on BSC galvanised NZWS personnel and scientists into learning how to prevent the same thing happening again elsewhere in New Zealand, how to deal with rats on islands and to develop active management techniques for endangered species. The transfer of South Island saddleback was recognised as the first avian taxa to be saved from imminent extinction and restored to viability in the wild by direct human intervention (Birdlife International 2013). Following the eradication of rats from BSC in 2006, saddleback have been returned to the island and land-bird, invertebrate and vegetation numbers have increased (McClelland et al.2011; Nevins \& Hester 2013). Monitoring of the titi population on BSC and other Titi Islands was undertaken collaboratively between Rakiura Maori and the University of Otago (Kia Mau Te Tìtī Mo Ake Tōnu Atu) between 1999 and 2013 (H. Moller pers. comm.). Burrow density does not appear to have increased on islands that had rats removed or those which have never had rats present suggesting the overall titi population decline may be due to a range of factors rather than just predation by rats (H. Moller pers. comm.; Nevins $\&$ Hester 2013). On-going biosecurity measures at departure points and through public awareness campaigns ('Keep the Titi Islands Rat Free') have been implemented to reduce the risk of accidentally re-introducing rats to BSC (P. McClelland pers. comm.; McClelland et al.2011). Enforcing these measures and maintaining on-going consultation, biosecurity checks and training with Rakiura Maori is vital to maintain the rat-free status of BSC.

The tragedy ofBSC was a valuable lesson for conservation personnel and served to convince even the most sceptical of scientists that rats were capable of inducing ecological collapse and extinction within naïve island faunas. The BSC rat irruption had a massive, enduring impact in shaping future conservation policy and practice both within New Zealand and on numerous islands around the world. Refined over the past 50 years, eradication technology has now reached a level where, with ongoing vigilance and effective biosecurity, it is possible to maintain the rodent-free status of biologicallyimportant islands, to eradicate rats and other alien invasive species from islands to restore the natural ecosystem, and to reintroduce endangered species.

\section{Acknowledgements}

The muttonbirding families, particularly the Macquaries, Waitiris and Bulls, for their hospitality on Big South Cape Island/Taukihepa before, during and after the rat irruption. The captain and crews of the New Zealand Navy harbour defence vessels Mako, Haku, Manga and Maroro, who 
assisted with transport to Big South Cape Island/Taukihepa and the surrounding islands during the transfer of saddleback and wren. The owners and staff of the Club Hotel, Bluff, for their assistance and support during the 1961, 1964 and 1965 Big South Cape visits. Jim O'Brien, Dick Veitch, John Gibbs and Peter Johns for their assistance during the 1964 "rescue" visit and John Kendrick, John Adams, Dick Anderson, Peter Ward and Ernie Sharpe for their assistance during the 1965 second saddleback trip to Big South Cape Island/Taukihepa. Bill McCulloch \& Gilbert McCulloch for transportation on their fishing boat Duncan to Big South Cape Island/Taukihepa during the 1961 survey. Henrik Moller provided information on the long-term research of titi on Big South Cape and other Titi Islands. Pete McClelland provided information on the 2006 rat eradication and biosecurity procedures for the island. Kelvin Floyd designed Figure 1 with map data sourced from the LINZ Data Service and licensed by LINZ for re-use under the Creative Commons Attribution 3.0 New Zealand licence. Anthony Phelps prepared the electronic versions of Figures 2 and 3 for publication from the original BDB slides. Dick Veitch and another anonymous reviewer commented on this paper.

\section{References}

Atkinson IAE 1973. Spread of the ship rat (Rattus r. rattus L.) in New Zealand. Journal of the Royal Society of New Zealand 3: 457-472.

Atkinson IAE 1985. The spread of commensal species of Rattus to oceanic islands and their effects on island avifaunas. In: Moors PJ ed Conservation of island birds. ICBP Technical Publication 3. Pp. 35-81.

Ballance A 2007. The tragedy of Big South Cape Island: 1964-1965. In: Ballance A ed Don Merton: the man who saved the black robin. Auckland, Reed Publishing (NZ) Ltd. Pp. 62-78.

Bell BD 1969. Titi Island - Marlborough Sounds. Unpublished report, Wildlife Branch File 18/4/4. Wellington, Department of Internal Affairs.

Bell BD 1978. The Big South Cape rat irruption. In: Dingwall PR, Atkinson IAE, Hay C eds The ecology and control of rodents in New Zealand nature reserves. Department of Lands and Survey Information Series No. 4. Pp. 33-45.

Bellingham PJ, Towns DR, Cameron EK, Davis JJ, Wardle DA, Wilmshurst JM, Mulder CPH 2010. New Zealand island restoration: seabirds, predators, and the importance of history. New Zealand Journal of Ecology 34: 115-136.

BirdLife International 2013. Philesturnus carunculatus. The IUCN Red List of Threatened Species. Version 2014.3. www.iucnredlist.org. (accessed 28 December 2014).

Blackburn A 1965. Muttonbird islands diary. Notornis 12: 191-207.

Clout MN, Russell JC 2006. The eradication of mammals from New Zealand islands. In: Koike F, Clout MN, Kawamichi M, De Poorter M, Iwatsuki K eds Assessment and control of biological invasion risks. Gland, Switzerland and Cambridge UK, IUCN and Kyoto, Japan, Shoukadoh Book Sellers. Pp. 127-141.

Clucas R 2011. Long-term trends of sooty shearwater (Puffinus griseus) populations revealed by harvest success. Ecological Applications 21: 1308-1326.

Clucas R, Moller H, Bragg C, Fletcher D, Lyver POB, Newman J 2012. Rakiura Māori muttonbirding diaries: monitoring trends in tìtì (Puffinus griseus) abundance in New Zealand.
New Zealand Journal of Zoology 39: 155-177.

Crawley MC 1983. Wildlife Service research priorities. Wildlife - a review 12: 5-26.

Daniel MJ 1990. Bats: order Chiroptera. In: King CM ed The handbook of New Zealand mammals. Auckland, Oxford University Press. Pp. 114-137.

Dingwall PR, Atkinson IAE, Hay C 1978. The ecology and control of rodents in New Zealand Nature Reserves. Department of Lands and Survey Information Series No 4. Wellington. $237 \mathrm{p}$.

Galbreath R 1993. Working for wildlife: a history of the New Zealand Wildlife Service. Wellington, Bridget Williams Books Ltd \& Department of Internal Affairs. 253 p.

Gill BJ, Bell BD, Chambers GK, Medway DG, Palma RL, Scofield RP, Tennyson AJD, Worthy TH 2010. Checklist of the birds of New Zealand, Norfolk and Macquarie Islands, and the Ross Dependency, Antarctica. 4th ed. Wellington, Ornithological Society of New Zealand and Te Papa Press. 464 p.

Guthrie-Smith H 1925. Bird life on island and shore. Edinburgh and London, William Blackwood and Sons. 195 p.

Guthrie-Smith H 1936. Sorrows and joys of a New Zealand naturalist. Dunedin, Reed. 252 p.

Lovegrove TG 1996. Island releases of saddleback (Philesturnus carunculatus) in New Zealand. Biological Conservation 77: 151-157.

Lyver POB 1999. Predation and harvest impacts on Sooty Shearwaters (Puffinus griseus). Unpublished $\mathrm{PhD}$ thesis. Dunedin, University of Otago.

Lyver POB, Moller H, Thompson C 1999. Changes in sooty shearwater Puffinus griseus chick production and harvest precede ENS0 events. Marine Ecology Progress Series 188: 237-248.

McClelland PJ, Coote R, Trow M, Hutchins P, Nevins HM, Adams J, Newman J, Moller H 2011. The Rakiura Tìtī Islands Restoration Project: community action to eradicate Rattus rattus and Rattus exulans for ecological restoration and cultural wellbeing. In: Veitch CR, Clout MN, Towns DR eds Island Invasives: eradication and management. Gland, Switzerland, IUCN. Pp. 451-454.

Merton DV 1965. Transfer of saddlebacks from Hen Island to Middle Chicken Island, January 1964. Notornis 12: 213-222.

Merton DV 1975. The saddleback: its status and conservation. In: Martin RD ed Breeding endangered species in captivity. London, Academic Press. Pp. 61-74.

Miskelly CM, de Lange P 2006. Notes on the breeding ecology of the extinct Stewart Island snipe (Coenocorypha aucklandica iredalei). Notornis 53: 339-352.

Miskelly CM, Powlesland RG 2013. Conservation translocations of New Zealand birds, 1863-2012. Notornis 60: 3-28.

Moller H, Nevins HM, Adams J 2003. The Rakiura titi restoration project: mitigation of the Command oil spill injury by eradication of rats from sooty shearwater breeding colonies in New Zealand. Unpublished report for Rakiura Titi Islands Administration Body. 78 p.

Moller H, Fletcher D, Johnson PN, Bell BD, Flack D, Bragg C, Scott D, Newman J, McKechnie S, Lyver POB 2009. Changes in sooty shearwater (Puffinus griseus) abundance and harvesting on the Rakiura Titi Islands. New Zealand Journal of Zoology 36: 325-34.

Moors PJ 1985. Eradication campaigns against Rattus norvegicus on the Noises Islands, New Zealand, using 
brodifacoum and 1080. International Council for Bird Preservation Technical Publication 3: 143-155.

Nevins HM, Hester M 2013. The Rakiura Tītī Islands Restoration Project: mitigation of the Command oil spill injury by eradication of rats from sooty shearwater breeding colonies in New Zealand-2012 Annual Report. Unpublished report to the Command Restoration Council.

O’Donnell C 1999. Search for pekapeka (bats) on Putauhina Island, southern Titi Islands, 6-9 November 1999. Christchurch, unpublished report Department of Conservation.

O’Donnell CFJ, Christie JE, Hitchmough RA, Lloyd B, Parsons S 2010. The conservation status of New Zealand bats, 2009. New Zealand Journal of Zoology 37: 297-311.

Riney T 1955. Rattus rattus on Big South Cape Island (Long) Island: 22 January 1955. Extract of Thane Riney's field notes on file 6/5/3 Ecology Division, DSIR.

Robins JH, Miller SD, Russell JC, Harper GA, Fewster RM 2016. Where did the rats of Big South Cape Island come from? New Zealand Journal of Ecology 40: 229-234.

Russell JC, Broome KG 2016. Fifty years of rodent eradications in New Zealand: another decade of advances. New Zealand Journal of Ecology 40: 197-204.
Scofield RP, Christie D 2002. Beach patrol records indicate a substantial decline in sooty shearwater (Puffinus griseus) numbers. Notornis 49: 158-16.

Stead EF 1936. The New Zealand saddlebacks. Transactions and proceedings of the Royal Society of New Zealand 66: 185-187.

Thomas BW, Taylor RH 2002. A history of ground-based rodent eradication techniques developed in New Zealand, 19591993. In: Veitch CR, Clout MN eds Turning the tide: the eradication of invasive species. Gland, Switzerland and Cambridge, UK, IUCN SSC Invasive Species Specialist Group. Pp. 301-310.

Towns DR, Broome KG 2003. From small Maria to massive Campbell: forty years of rat eradications from New Zealand islands. New Zealand Journal of Zoology 30: 377-398.

Veitch CR, Bell BD 1990. Eradication of introduced animals from the islands of New Zealand. In: Towns DR, Daugherty $\mathrm{CH}$, Atkinson IAE eds Ecological restoration of New Zealand islands. Conservation Sciences Publication No. 2. Wellington, Department of Conservation. Pp. 137-146.

Watson JS 1956. The present distribution of Rattus exulans (Peale) in New Zealand. New Zealand Journal of Science and Technology 37: 560-570.

Wilson RA 1959. Bird islands of New Zealand. Christchurch, Whitcombe \& Tombs. 